\title{
Editorial
}

\section{Photoactive Nanomaterials}

\author{
Nurxat Nuraje (1)
}

check for updates

Citation: Nuraje, N. Photoactive Nanomaterials. Nanomaterials 2021, 11,77. https://doi.org/10.3390/ nano11010077

Received: 25 December 2020 Accepted: 29 December 2020 Published: 1 January 2021

Publisher's Note: MDPI stays neutral with regard to jurisdictional clai$\mathrm{ms}$ in published maps and institutional affiliations.

Copyright: () 2021 by the author. Licensee MDPI, Basel, Switzerland. This article is an open access article distributed under the terms and conditions of the Creative Commons Attribution (CC BY) license (https:// creativecommons.org/licenses/by/ $4.0 /)$.
Department of Chemical and Materials Engineering, School of Engineering and Digital Science, Nazarbayev University, 53 Kabanbay Batyr Avenue, Nur-Sultan 010000, Kazakhstan; nurxat.nuraje@nu.edu.kz

With the depletion of carbon-based energy resources and the consideration of global warming, renewable energy is considered a promising energy source for future energy. Solar energy has shown the greatest potential to meet global energy needs with its ample source and free availability. Although primitive photovoltaic work gets credited to the silicon-based works done in the bell lab, recently, progress in the photovoltaic cell is significant. For example, many different types of solar cells have appeared, which include dye-sensitized solar cells, quantum-based solar cells, polymer solar cells, perovskite solar cells, etc. Here, we can point out the perovskite solar cell which reaches $25 \%$ efficiency within a short period. According to the literature search done on the Web of science, the number of publications on perovskite solar cells has increased exponentially within the last 10 years.

In addition to photovoltaic application, many research areas in utilization of solar energy have been extensively exploited to form distinct disciplines. One of them, photocatalytic water splitting, has molded a promising research pathway with exponentially increasing publications. Other fields include fuel generation from carbon dioxide, nitrogen conversion, photodegradation of organic and inorganic pollutants, and optoelectronic devices. Besides the fields mentioned, photoactive nanomaterials have been used in other fields. Experimental and theoretical investigations of solar energy conversion using various simulation software, from material design to reaction kinetics, lay the groundwork to improve the efficiency of the above applications. Furthermore, the fundamental study of photoactive nanomaterials in solar energy conversion, which is done through designing advanced functional materials and advanced experimental techniques, focuses on light harnessing, charge separation/recombination, and catalytic reaction kinetics.

Therefore, it is very important to deliver the recent research progress in the field of photoactive nanomaterials to the scientific community. Thus, the scope of this Special Issue not only covers a basic study of the solar energy conversion process with simulations but also targets certain applications including environmental remediation, optoelectronic devices, and solar fuel generation. This Special Issue includes six research articles and three review articles to focus on photoactive nanomaterials from fundamental research on their applications. Three research works [1-3] reported recent emerging materials, including $2 \mathrm{D} \mathrm{Bi}_{2} \mathrm{Se}_{3}$ in optoelectronic applications, and discussed fundamental behaviors of dyes in confined media. Another research work reported by Maxim et al. [4] explores the enhancement of light harnessing in perovskite solar cells with embedded carbon quantum dots. Most of the articles are focused on photocatalytic solar fuel generation. Hydrogen generation kinetics is studied via silicon nanocrystals in aqueous media [5]. Nanocomposite-based photocatalysts including $\mathrm{TiO}_{2}, \mathrm{SrTiO}_{3}$, and Polyaniline (PANI) are also reviewed to give quick updates regarding photocatalytic water splitting [6-8]. Shabdan et al. updated with recent progress in a promising oxygen evolution of $\mathrm{WO}_{3}$-based photocatalysts [9].

Therefore, I think it is essential to present a Special Issue which provide recent research works on photoactive nanomaterials, from fundamental studies to recent applications including optoelectronic devices, perovskite solar cells, and photocatalytic water splitting. 
Funding: This research was funded by Nazarbayev University FGRG grant number SEDS2020 016.

Institutional Review Board Statement: Not applicable.

Informed Consent Statement: Not applicable.

Conflicts of Interest: The authors declare no conflict of interest.

\section{References}

1. Sola-Llano, R.; Oliden-Sánchez, A.; Alfayate, A.; Gómez-Hortigüela, L.; Pérez-Pariente, J.; Arbeloa, T.; Hofkens, J.; Fron, E.; Martínez-Martínez, V. White Light Emission by Simultaneous One Pot Encapsulation of Dyes into One-Dimensional Channelled Aluminophosphate. Nanomaterials 2020, 10, 1173. [CrossRef] [PubMed]

2. Wang, S.; Li, Y.; Ng, A.; Hu, Q.; Zhou, Q.; Li, X.; Liu, H. 2D Bi ${ }_{2} \mathrm{Se}_{3}$ van der Waals Epitaxy on Mica for Optoelectronics Applications. Nanomaterials 2020, 10, 1653. [CrossRef] [PubMed]

3. Zeng, Q.; Guo, S.; Sun, Y.; Li, Z.; Feng, W. Protonation-Induced Enhanced Optical-Light Photochromic Properties of an InorganicOrganic Phosphomolybdic Acid/Polyaniline Hybrid Thin Film. Nanomaterials 2020, 10, 1839. [CrossRef] [PubMed]

4. Maxim, A.A.; Sadyk, S.N.; Aidarkhanov, D.; Surya, C.; Ng, A.; Hwang, Y.-H.; Atabaev, T.S.; Jumabekov, A.N. PMMA Thin Film with Embedded Carbon Quantum Dots for Post-Fabrication Improvement of Light Harvesting in Perovskite Solar Cells. Nanomaterials 2020, 10, 291. [CrossRef] [PubMed]

5. Mussabek, G.; Alekseev, S.A.; Manilov, A.I.; Tutashkonko, S.; Nychyporuk, T.; Shabdan, Y.; Amirkhanova, G.; Litvinenko, S.V.; Skryshevsky, V.A.; Lysenko, V. Kinetics of Hydrogen Generation from Oxidation of Hydrogenated Silicon Nanocrystals in Aqueous Solutions. Nanomaterials 2020, 10, 1413. [CrossRef] [PubMed]

6. Fu, Y.-S.; Li, J.; Li, J. Metal/Semiconductor Nanocomposites for Photocatalysis: Fundamentals, Structures, Applications and Properties. Nanomaterials 2019, 9, 359. [CrossRef] [PubMed]

7. Bakbolat, B.; Daulbayev, C.; Sultanov, F.; Beissenov, R.; Umirzakov, A.; Mereke, A.; Bekbaev, A.; Chuprakov, I. Recent Developments of $\mathrm{TiO}_{2}$-Based Photocatalysis in the Hydrogen Evolution and Photodegradation: A Review. Nanomaterials 2020, 10, 1790. [CrossRef] [PubMed]

8. Sultanov, F.; Daulbayev, C.; Azat, S.; Kuterbekov, K.; Bekmyrza, K.; Bakbolat, B.; Bigaj, M.; Mansurov, Z. Influence of Metal Oxide Particles on Bandgap of 1D Photocatalysts Based on $\mathrm{SrTiO}_{3} /$ PAN Fibers. Nanomaterials 2020, 10, 1734. [CrossRef] [PubMed]

9. Shabdan, Y.; Markhabayeva, A.; Bakranov, N.; Nuraje, N. Photoactive Tungsten-Oxide Nanomaterials for Water-Splitting. Nanomaterials 2020, 10, 1871. [CrossRef] [PubMed] 